\title{
Topical issues of digitalization in corporate law
}

\author{
Elena Viktorovna Oleynik ${ }^{1}$ and Olga Mikhailovna Shevchenko \\ Kutafin Moscow State Law University, Department of Business and Corporate Law, Moscow, Russia
}

\begin{abstract}
The purpose of the study is to analyze the provisions of the novelties of the Russian legislation on digital financial assets and digital currency. The methodological basis was the method of comparative legal analysis, using which the authors identify general patterns and features of the legal status of Russian digital joint-stock companies and decentralized autonomous organizations widely discussed in foreign literature. The results of the study were conclusions about the significant differences between the above organizations. A company issuing digital shares, under Russian law, differs from an ordinary non-public joint stock company by limiting the circulation of digital shares within the framework of a digital platform. Unlike the decentralized autonomous organization, it has legal entity and governing bodies. It was also concluded that there is a significantly greater variety of rights of holders of foreign token-shares in comparison with the rights of shareholders of Russian digital joint stock companies. The novelty of the research is contained in the results of the analysis and doctrinal interpretation of the norms of Russian federal laws concerning digital shares. So, in particular, it was established that such are recognized at the same time as securities and digital rights. Such a legal structure appears to be unnecessarily complex. According to Russian law, digital shares differ from ordinary shares in the form of certification of shareholders "rights, while no differences have been revealed in the scope of shareholders" rights.

Keywords: corporation, digital joint stock company, decentralized autonomous organization, digital assets, promotion
\end{abstract}

\section{Introduction}

The digitalization of business dictates the requirements for creating a legal environment for the existence and development of digital technologies. In the modern period in Russia, there is a tendency to introduce digital technologies into corporate law. The literature actively discusses the use of a distributed ledger system (blockchain) in corporations, the conclusion of smart contracts, the issuance of digital shares, etc.

The issues of digitalization in corporate law are quite discussed both in our country and abroad. In Russia, these problems are actively studied by V.A. Laptev, L.V. Sannikova, Yu.S. Kharitonova, S.A. Chekhovskaya and others. Among foreign researchers of this issue, one can name such authors as K.M. Bruner, E. Vermoulin, R. Kulms, A. Sims, N. Tse and others.

${ }^{1}$ Corresponding author: levole@mail.ru 
The adoption of the Russian federal law on digital financial assets (hereinafter referred to as the DFA Act), introducing a new institution of joint stock companies (JSC), the shares of which are issued in the form of digital financial assets, requires a theoretical understanding of its provisions, including in comparative legal aspect. This is the purpose of this study. The authors set the following tasks:

- to analyze the legal status of the Russian digital joint-stock company and compare this entity with the concept of "decentralized autonomous organization (DAO)" used in foreign literature, identify the general and the particular;

- to analyze the legal nature of shares issued in the form of digital financial assets (hereinafter referred to as digital shares) under Russian law, and compare them with share tokens studied in foreign legal doctrine.

\section{Methods}

The authors used the methods of doctrinal interpretation of legal norms, comparative jurisprudence. In order to take into account the latest trends in economic relations and legal thought, scientific research published over the past 5 years, including foreign articles included in the Westlaw database, was selected for analysis.

\section{$3 \quad$ Results}

Western doctrine is actively discussing the status of DAOs, which have not yet received the proper legal framework, which some researchers see as a more technological replacement for traditional corporations. Dash, Tezos, DFINITY, DAOstack, Aragon, Barter, Minter, and even Bitcoin are cited as examples of digital entities characterized as DAOs.

One of the goals of the Russian DFA Act is to legalize token shares used in global practice for equity capital crowdfunding [1,2], including to certify the rights of DAO participants.

The similarity between digital JSC and DAO is seen in the digital form of certifying the rights of their participants and the use of distributed ledger technology (blockchain). When comparing the Russian digital JSC with the characteristic features of DAO identified by foreign researchers, we note significant differences presented in Table 1.

Table 1. Characteristic features: DAO vs digital JSC.

\begin{tabular}{|c|c|c|}
\hline Distinctive features & DAO & $\begin{array}{c}\text { Digital JSC under Russian } \\
\text { law }\end{array}$ \\
\hline Legitimation as a legal entity & No & Yes \\
\hline $\begin{array}{c}\text { The presence of a sole } \\
\text { executive body }\end{array}$ & Absent \\
\hline $\begin{array}{c}\text { The presence of collegial } \\
\text { governing bodies }\end{array}$ & $\begin{array}{c}\text { DAO voting on selected issues } \\
\text { combined with automated } \\
\text { governance }\end{array}$ & $\begin{array}{c}\text { Management is carried out by } \\
\text { the general meeting of } \\
\text { shareholders, collegial and sole } \\
\text { bodies of the company }\end{array}$ \\
\hline Decision making & Yes & No \\
\hline $\begin{array}{c}\text { Using smart contracts to } \\
\text { manage activities }\end{array}$ & $\begin{array}{c}\text { Unified principles of liability } \\
\text { have not been developed by } \\
\text { world practice }\end{array}$ & $\begin{array}{c}\text { The rules for holding } \\
\text { shareholders accountable are } \\
\text { similar to those of a regular } \\
\text { JSC }\end{array}$ \\
\hline \begin{tabular}{c} 
Liability of the members \\
\hline
\end{tabular} & \multicolumn{2}{|c}{} \\
\hline
\end{tabular}




\begin{tabular}{|c|c|c|}
\hline $\begin{array}{c}\text { Name of the form of } \\
\text { certification of shareholders' } \\
\text { rights }\end{array}$ & Equity tokens & $\begin{array}{c}\text { Shares issued as digital } \\
\text { financial assets (digital shares) }\end{array}$ \\
\hline Scope of shareholders' rights & $\begin{array}{c}\text { The rights are more varied than } \\
\text { the rights traditionally granted } \\
\text { to holders of common and } \\
\text { preferred shares }\end{array}$ & $\begin{array}{c}\text { The rights are similar to the } \\
\text { rights of holders of ordinary or } \\
\text { preferred shares stipulated by } \\
\text { the legislation of the Russian } \\
\text { Federation }\end{array}$ \\
\hline
\end{tabular}

\section{Discussion}

\subsection{Legal status of digital JSC}

To date, in Russia, amendments have been made to the federal law on joint-stock companies (JSC Act) regarding the fact that newly created non-public companies have the opportunity to issue shares in the form of digital financial assets (DFA). In practice, such societies are called digital JSCs. The system of management and control bodies of a digital JSC does not differ from an ordinary joint-stock company. The JSC Act establishes the following restrictions: 1) no amendments or additions may be made to the charter of operating companies in terms of indicating the possibility of issuing shares in the form of a DFA; 2 ) it is impossible to change the status of a digital JSC to public.

Let us compare the Russian digital JSC with the well-known foreign doctrine of the DAO, which is created without registration as a legal entity by issuing tokens as a virtual organization with an automated management mechanism, where there is no sole executive body and a board of directors.

DAO is defined in various ways: as "a decentralized application that encourages users to participate in activities that achieve agreed business goals, allowing them to work together without requiring them to trust each other" [3]; as "an organization that has rules encoded in computer programs called "smart contracts" [4], etc. "Innovative business prefers flexible and simple corporate governance" [5]. Voting of DAO participants is carried out using blockchain technology, and the implementation of decisions made using smart contracts.

Literature [6-12] highlights the merits of DAO, such as transparency of operations and decisions (without "pressure" from the board of directors); reducing the costs of the management agency, avoiding corporate conflicts; and disadvantages, such as legal uncertainty; unclear legal status; technical problems and shortcomings of blockchain technology, etc. There are obvious significant differences between Russian digital JSCs and DAOs, which the authors have already noted in the Results section.

\subsection{The legal nature of digital shares}

According to Russian legislation, shares issued in the form of a digital asset are classified as digital rights, while the shares are recognized as issue-grade uncertificated securities (UCS). The question arises about the admissibility of the merger of two categories of objects of civil rights that are different for the Russian legal system (digital rights and UCS) in one object.

Digital shares are not subject to many of the accounting rules for UCS rights maintained by way of account entries. Their accounting should be kept in accordance with the rules of the information system in which they apply. In practice, digital asset accounting is based on blockchain.

The Russian doctrine notes that it is necessary to distinguish between the digital and electronic forms of the existence of a record [13, 14]; at the same time, "there are no fundamental differences between digital rights and UCS, except for the infrastructure 
supporting the turnover of values" [15]. It was noted that shares issued in the form of a digital asset "can be simultaneously attributed to both the UCS and digital rights" [16]. In our opinion, the assignment of digital shares to two types of objects of civil rights at once introduces unnecessary difficulties in the interpretation of the rules of law and can cause practical difficulties and disputes.

By comparison, US law does not have the problem of categorizing digital shares as "security". The form of existence of a set of rights characterized as a share is secondary there [17], which makes it possible to extend to digital shares the general requirements provided for by The Securities Act of 1933, with the features provided for by the so-called the "JOBS Act" of 2012 [18]. We believe that Russian digital shares should be recognized as securities securing the rights of shareholders in a new special form - digital.

\subsection{Scope of rights owned by shareholders of digital JSCs}

The Russian JSC Act does not provide for any special rights granted to holders of digital shares as compared to the rights of holders of ordinary shares (common or preferred). A feature of digital shares is that their issue, accounting and circulation are possible only by making entries in the information system (i.e., they are limited in circulation). Conversion, including during the reorganization of the company, of digital shares into ordinary ones is not allowed. Thus, Russian digital shares differ from ordinary shares not in the content of shareholders' rights, but in the form of their certification and the procedure for transferring them.

If we compare the content of the rights of holders of Russian digital shares with the rights of holders of DAO tokens, then the latter, not being bound by the requirements of the law, are characterized by a much wider variety of options for certified rights and their combinations. For example, foreign studies mention the types of DAO tokens based on the reputation that a DAO participant acquires as a result of the function he performs (miner, master node, etc.), which can be used, for example, to put forward an offer or to obtain other benefits and privileges.

\section{Conclusion}

In conclusion, it can be noted that, with the adoption of the DFA Act, the Russian legislator took a step forward in creating a legal framework for digital organizations, at the same time; the existing norms are still not enough to properly regulate this phenomenon.

\section{References}

1. T. Huang, Y. Zhao, C.L.S. Rev. 33(6), 802-810 (2017). https://doi.org/10.1016/j.clsr.2017.05.016

2. W.A.A.W. Haniff, A.H.Ab Halim, R. Ismail, Int. J. Asian Soc. Sci. 9(8), 450-460 (2019). https://doi.org/10.18488/journal.1.2019.98.450.460

3. S. Makridakis, et al., Blockchain: The Next Breakthrough, in M.A. Aceves-Fernandez (ed.), Rapid Progress of AI in Artificial Intelligence: Emerging Trends and Applications (IntechOpen, London, 2018). https://doi.org/10.5772/intechopen.75668

4. P. De Filippi, A. Wright, Blockchain and the Law: The Rule of Code (Harvard University Press, Cambridge, Massachusetts, 2018)

5. S.A. Chekhovskaya, Entrepreneurial Law, 3, 31-41 (2018) 
6. A. Sims, New Zealand Univ. Law Rev. 28, 423-458 (2019). https://doi.org/10.2139/ssrn.3524674

7. R. Kulms, Singapore J. Leg. Stud. 63-89 (Mar. 2020)

8. Ch.M. Bruner, The Cambridge Law J. 79(3), 431-458 (2020). https://doi.org/10.1017/S0008197320000756

9. N. Tse, Univ. Wellington Law Rev. 51(2), 313-356 (2020). https://doi.org/10.26686/vuwlr.v51i2.6573

10. C. Jentzsch, Decentralized autonomous organization to automate governance, in Creation of smart-contracting collaborations for decentralized autonomous organizations. Int. Conf. on Business Informatics Research, Norta, A., 2015, August 3 17 (Springer, Cham, 2016)

11. Benjamin P. Edwards, Carla L. Reyes, \& Nizan Geslevich Packin. Companies Face Risk and Opportunity with Distributed Governance Structures, COLUM. L. SCH.: CLS BLUE SKY BLOG (Jan. 19, 2017)

12. T.A. Hüllmann, Are Decentralized Autonomous Organizations the Future of Corporate Governance? (2018). https://doi.org/10.13140/RG.2.2.34344.88327

13. L.V. Sannikova, Yu.S. Kharitonova, Law, 9, 86-95 (2018)

14. T.V. Uvakina, Civil Law, 3, 13-16 (2019). https://doi.org/10.18572/2070-2140-2019-313-16

15. A. Guznov, et al., Law, 5, 16-30 (2018)

16. V.A. Laptev, O.A. Tarasenko (eds.), Tsifrovaya ekonomika: kontseptualnye osnovy pravovogo regulirovaniya biznesa $v$ Rossii [Digital economy: conceptual foundations of legal regulation of business in Russia] (Prospect, Moscow, 2020). https://doi.org/10.31085/9785392328604-2020-488

17. O.M. Shevchenko, Pravovoe regulirovanie rynka tsennykh bumag i kollektivnykh investitsii [Legal regulation of the securities market and collective investments] (Prospect, Moscow, 2021). https://doi.org/10.31085/9785392328741-2021-456

18. V.V. Blazheev, M.A. Egorova (eds.), Tsifrovoe pravo [Digital law] (Prospect, Moscow, 2021). https://doi.org/10.31085/9785392227297-2020-640 